\title{
Manajemen Pengembangan SDM KePendidikan Bermutu di Perguruan Tinggi
}

\author{
Nur Ali Rahman \\ Dosen Fakultas Tarbiyah Universitas Islam Negeri (UIN) Malang
}

\begin{abstract}
The evolving culture of our contemporary society continues to have an ongoing and profound effect on the practice of educational human resources management in university, because a good society can be performed through a good performance of individual. Human resources whose a good performance can be educated in an excellence university. In realities, the excellence universities are changed by the good human resources including an educational staffs, practicing central-office administrators and building principals who want to become more familiar with the field of human resources management.
\end{abstract}

This article tries to discuss about management of quality educational human resources development in university.

Keywords: human resources, management, quality educational

\section{A. Pendahuluan}

Kompleksitas permasalahan yang muncul di permukaan dan lahirnya masyarakat "sizofrenia" - yaitu masyarakat dengan kepribadian terbelah antara keyakinan dan pengamalannya yang tidak merasa bersalah jika dia telah membuat sesuatu yang salah (Tilar, HAR., 1999, hal. 95) - bersumber pada lingkungan masyarakat, lingkungan keluarga dan lingkungan perguruan tinggi atau sekolah. Karena itu di dalam ketiga lingkungan tersebut perlu ada "suri tauladan" bagi lingkungannya. Masyarakat yang baik hanya dapat dibentuk dengan menampilkan Sumber Daya Manusia (SDM) dengan karakter yang baik. Sumber daya manusia yang berkarakter baik dapat dibentuk melalui pendidikan yang baik. Dengan demikian, mutu masyarakat banyak dipengaruhi oleh mutu pendidikan tinggi, sedangkan mutu pendidikan tinggi banyak dipengaruhi oleh mutu SDM kependi- 
dikannya. Rendahnya mutu pendidikan pada berbagai jenjang dan jenis pendidikan sebenarnya merupakan refleksi dari rendahnya mutu SDM kependidikan di perguruan tinggi.

\section{B. Manajemen Pengembangan SDM Kependidikan Bermutu di Perguruan Tinggi}

Mutu pendidikan merupakan masalah mikro pendidikan, sehingga ia tidak bisa diselesaikan secara makro. Mutu pendidikan sangat terkait dengan persoalan mutu sumber daya manusia (SDM) kependidikan yang di antaranya; kemampuan dosen, kemampuan pimpinan, kemampuan tenaga administrasi, kesiapan perguruan tinggi dalam menyediakan fasilitas yang diperlukan, dan masyarakat pendukung pendidikan yang ada di wilayahnya. Karena itu, peningkatan mutu pendidikan tinggi terkait dengan manajemen pengembangan SDM kependidikan di perguruan tinggi. Manajemen pengembangan SDM kependidikan di perguruan tinggi baru dapat dilakukan jika didukung ketersediaan data mengenai SDM tenaga kependidikan baik secara lokal maupun nasional. Untuk itu, langkah yang perlu segera dilakukan adalah memetakan situasi SDM kependidikan secara lokal, yang didukung ketersediaan data terbaru secara lengkap.

Hasil pemetaan situasi SDM kependidikan tersebut akan mengklasifikasikan SDM kependidikan di perguruan tinggi tertentu berdasarkan kategorisasi-kategorisasi tertentu. Menurut Nur Ali (2004) ada empat kategori perguruan tinggi (PT). Pertama, PT dengan kategori pra-formal, yaitu PT yang sebenarnya tidak layak dianggap sebagai sebuah perguruan tinggi, sebab belum didukung ketersediaaan sarana belajar, termasuk dosen yang memadai. Kedua, PT formal yaitu PT yang sudah memiliki sarana dan Dosen yang cukup, namun proses belajar masih berjalan sekedarnya saja. Ketiga, PT transisional, yaitu PT yang sudah memiliki fasilitas lebih dibandingkan PT formal, bahkan mutu pendidikan yang diselenggarakan sudah baik, hanya belum memiliki kemandirian. Keempat, PT otonom, yaitu PT yang kondisi kampusnya yang diharapkan sudah terwujud sehingga sudah mampu mengelola pendidikan dan menghasilkan lulusan yang bermutu tinggi. 
Di dalam keempat kategori perguruan tinggi tersebut, mutu SDM kependidikannya antara yang satu dengan lainnya berbeda-beda, oleh karena itu perlakuan pembinaan dan pengembangan SDM yang diberikan perlu dibedakan sesuai dengan kategori PT tersebut. Untuk itu, pengembangan SDM kependidikan di PT perlu mendasarkan pada peta kategorisasi SDM nya. Ada tiga kelompok perguruan tinggi yang diklasifikasikan berdasarkan ciri-ciri SDM kependidikannya yaitu; (a) kelompok mapan, (b) kelompok transisi, dan (c) kelompok terbelakang (Rebore, 1984; Cooper, $\mathrm{dkk}$, 2004).

Adapun aspek-aspek yang perlu dianalisis dalam manajemen pengembangan sumber daya manusia kependidikan di perguruan tinggi yang memiliki pengaruh cukup signifikan pada mutu layanan dan lulusan-nya di antaranya adalah; (a) aspek penyediaan dan pemanfaatan SDM kependidikan, (b) aspek perekrutan dan proses seleksi, (c) aspek penilaian prestasi kerja, dan (d) aspek metode penilaian prestasi kerja. (Rebore, 2004).

\section{Aspek Penyediaan dan Permanfaatan SDM Kependidikan:}

Penyediaan dan pemanfaatan SDM kependidikan di perguruan tinggi secara sederhana dapat dikelompokkan menjadi tiga kelompok dengan ciri-ciri sebagai berikut: 


\begin{tabular}{|c|c|}
\hline KELOMPOK & CIRI-CIRI \\
\hline 1. Kelompok Mapan & $\begin{array}{l}\text { a. Memiliki SDM yang cukup } \\
\text { b. Perekrutan SDM dilakukan secara obyektif dan } \\
\text { berdasarkan analisis kebutuhan yang obyektif } \\
\text { pula } \\
\text { c. Pembagian tugas dan wewenang yang jelas } \\
\text { khususnya antara tugas edukasional dan } \\
\text { administrasi } \\
\text { d. Jalur karir yang jelas dan terencana } \\
\text { e. Penilaian prestasi kerja dan imbalan yang jelas } \\
\text { dan obyektif } \\
\text { f. Kesempatan pengembangan yang terbuka }\end{array}$ \\
\hline 2. Kelompok Transisi & $\begin{array}{l}\text { a. Memiliki SDM yang cukup } \\
\text { b. Perekrutan SDM dilakukan secara obyektif tapi } \\
\text { masih berdasarkan analisis kebutuhan yang } \\
\text { belum obyektif } \\
\text { c. Pembagian tugas dan wewenang (edukasional dan } \\
\text { administrasi) cukup jelas pada tingkat tertentu } \\
\text { d. Jalur karir yang cukup jelas tapi belum terencana. } \\
\text { e. Penilaian prestasi kerja dan imbalan yang jelas } \\
\text { tapi belum obyektif } \\
\text { f. Kesempatan pengembangan terbuka pada tingkat } \\
\text { tertentu }\end{array}$ \\
\hline 3. Kelompok Terbelakang & $\begin{array}{l}\text { a. Memiliki SDM yang kurang } \\
\text { b. Pembagian tugas dan wewenang yang tidak jelas, } \\
\text { jabatan/tugas edukasional dirangkap dengan } \\
\text { jabatan/tugas administrasi. Bahkan kewenangan } \\
\text { mengajar tidak jelas batas-batasannya } \\
\text { c. Jalur karir yang tidak jelas dan tidak } \\
\text { direncanakan } \\
\text { d. Penilaian prestasi kerja dan imbalan tidak jelas } \\
\text { dan subyektif } \\
\text { e. Belum dikembangkan program pengembangan } \\
\text { SDM }\end{array}$ \\
\hline
\end{tabular}

\section{Aspek Perekrutan dan Proses Seleksi}

Sumber kandidat dalam perekrutan dapat diperoleh dari dalam dan dari luar perguruan tinggi. Kedua sumber ini masing-masing mempunyai keunggulan dan kekurangan antara lain sebagai berikut: 
Sumber Kandidat;

\begin{tabular}{|c|c|c|}
\hline $\begin{array}{l}\text { Keunggulan/ } \\
\text { Kekurangan }\end{array}$ & $\begin{array}{c}\text { Dari dalam } \\
\text { Perguruan tinggi }\end{array}$ & $\begin{array}{c}\text { Dari Luar } \\
\text { Perguruan tinggi }\end{array}$ \\
\hline Keunggulan & $\begin{array}{l}\text { 1. Murah, mudah dan cepat } \\
\text { 2. Memperkecil arus keluar } \\
\text { masuk pegawai } \\
\text { 3. Mengurangi resiko } \\
\text { pengangkatan pegawai yang } \\
\text { mempunyai komitmen yang } \\
\text { rendah terhadap organisasi } \\
\text { 4. Dapat meningkatkan moral } \\
\text { pegawai }\end{array}$ & $\begin{array}{l}\text { 1. Kandidat meluas, sehingga } \\
\text { besar peluang memperoleh } \\
\text { tenaga unggul } \\
\text { 2. Tingkat produktivitas } \\
\text { meningkat lebih cepat } \\
\text { karena suasana baru, tukar } \\
\text { pengalaman dan suasana } \\
\text { kerja yang bersaing } \\
\text { 3. Memperluas hubungan } \\
\text { dengan masyarakat sehingga } \\
\text { tingkat kepercayaan } \\
\text { masyarakat terhadap } \\
\text { organisasi semakin tinggi }\end{array}$ \\
\hline Kekurangan & $\begin{array}{l}\text { 1. Kandidat terbatas, sehingga } \\
\text { kecil peluang memperleh } \\
\text { bibit unggul. } \\
\text { 2. Dapat menimbulkan } \\
\text { imbreeding pada } \\
\text { produktivitas. } \\
\text { 3. Dapat menimbulkan } \\
\text { diskriminasi pegawai akibat } \\
\text { perbedaan kemampuan yang } \\
\text { mencolok sehingga } \\
\text { menimbulkan keresahan } \\
\text { sosial dikalangn pegawai. }\end{array}$ & $\begin{array}{l}\text { 1. Mahal, kompleks dan } \\
\text { memakan waktu lama. } \\
\text { 2. Pegawai lama yang } \\
\text { mempunyai komitmen } \\
\text { tinggi mudah tergeser, } \\
\text { sehingga memungkinkan } \\
\text { arah tujuan PT } \\
\text { menyimpang. } \\
\text { 3. Memerlukan program } \\
\text { orientasi }\end{array}$ \\
\hline
\end{tabular}

\section{Aspek Penilaian Prestasi Kerja}

Penilaian prestasi kerja adalah proses penilaian prestasi kerja tenaga kependidikan (karyawan) yang bertujuan untuk memperoleh gambaran tentang prestasi kerja dan memberikan umpan balik kepada karyawan tentang pelaksanaan kerja pada waktu tertentu. Penilaian prestasi kerja tidak hanya bermanfaat bagi manajemen tetapi juga kepada karyawan itu sendiri, antara lain: 
1. Mendorong perbaikan prestasi kerja karyawan. Para karyawan berusaha untuk mendapat penilaian yang baik dan hasilnya memberikan umpan balik kepada karyawan dan manajemen untuk melakukan pembetulan dan perbaikan prestasi.

2. Dasar penyesuaian kompensasi. Penilaian prestasi kerja membantu menajemen dalam menentukan kenaikan upah, pemberian bonus dan atau imbalan lain yang berdasarkan merit system.

3. Dasar penempatan. Hasil penilaian prestasi kerja sangat membantu dalam melakukan promosi, transfer dan demosi.

4. Kebutuhan-kebutuhan pelatihan dan pengembangan. Prestasi kerja yang rendah mungkin menunjukkan kebutuhan akan pelatihan. Sebaliknya, prestasi yang tinggi mungkin menunjukkan prestasi yang perlu dikembangkan.

5. Perencanaan dan pengembangan karir.

6. Dasar untuk melakukan perbaikan proses stafing, informasi manajemen sumber daya manusia dan desain pekerjaan.

7. Perbaikan kesempatan kerja yang adil.

8. Bahan untuk mengevaluasi pengaruh faktor-faktor eksternal.

\section{Aspek Metode Penilaian Prestasi Kerja}

Secara umum penilaian prestasi kerja dapat dikelompokkan atas dua kelompok yaitu metode-metode penilaian berorientasi masa lalu dan berorientasi masa depan. Antara lain:

a. Metode penilaian berorientasi masa lalu

Metode ini menggunakan prinsip penilaian prestasi kerja yang dialami karyawan pada masa lalu.

Keunggulannya adalah obyek yang akan dinilai jelas dan mudah diukur karena peristiwanya telah terjadi.

Kelemahannya adalah tidak mempertimbangkan potensi pengembangan prestasi masa mendatang dan sepanjang kehidupan kerja karyawan harus direkam dengan baik. Metode tersebut antara 
lain : rating scale, cheaklist, critical incident method, field review method, atau dengan melakukan ujian obyektif dan observasi langsung.

b. Metode penilaian berorientasi masa depan

Metode ini memusatkan perhatian pada penilaian prestasi melalui penilaian-penilaian prestasi karyawan untuk berkembang dan berprestasi pada waktu mendatang. Keunggulannya adalah memberi motivasi dalam pengembangan diri dan menguntungkan organisasi pada masa mendatang. Kelemahannya adalah harus ditetapkan ukuran dan kriteria yang jelas dan obyektif karena yang akan dinilai tidak konkrit dan belum terjadi.

Beberapa metode/teknik yang biasa digunakan dalam penilaian berorientasi masa depan adalah:

a. Selfappraisals (Penilaian diri sendiri)

Teknik ini bermanfaat bila tujuan evaluasi adalah untuk melanjutkan pengembangan diri. Bila karyawan menilai dirinya sendiri maka penilaian defensi cenderung tidak terjadi sehingga upaya perbaikan diri cenderung dilaksanakan.

b. Psykological appraisals (Penilaian psikologis)

Penilaian ini bisanya dilakukanatas bantuan para psikolog untuk menilai potensi karyawan pada masa mendatang yang berkaitan dengan intelektual, emosi, motivasi, dan kepribadian.

c. Pendekatan management by objectives (MBO)

Manajemen by objective ini pertama kali dipopulerkan sebagai pendekatan oleh Peter Drucker (1954). Dalam pendekatan ini tenaga kependidikan dan atasan bersama-sama menetapkan tujuan-tujuan dan sasaran pelaksanaan kerja masa akan datang lalu berdasarkan itu dilakukan penilaian prestasi kerja secara bersama-sama pula. Salah satu formula yang dapat digunakan untuk menentukan prestasi kerja yaitu: 


$$
P=f(M \times K)
$$

Keterangan: $\quad \mathrm{P}=$ prestasi kerja

$\mathrm{M}=$ motivasi

$\mathrm{K}=$ kemampuan

Fatah, N. (2001, hal. 16).

d. Manajemen berbasis orang.

Manajemen ini merupakan suatu konsep manajemen modern yang mengkaji keterkaitan dimensi perilaku, komponen sistem dalam kaitannya dengan perubahan dan pengembagan SDM dan organisasi. Menurut model manajemen ini, pimpinan perguruan tinggiyang pada umumnya bekerja pada lingkungan yang menuntut untuk berubah sebagai akibat dari bertambahnya tuntutan dan kebutuhan masyarakat terhadap pendidikan anaknya, perlu menyesuaikan diri dengan perkembangan masyarakat. Salah satu upaya yang paling penting adalah melalui pengembangan sumber daya manusia kependidikannya.

e. Pendekatan melalui pusat penilaian.

Di sini manajemen mempunyai pusat-pusat penilaian yang melakukan penilaian prestasi kerja karyawan berdasarkan kriteria dan ukuran yang telah dibakukan.

\section{Penutup}

Berdasarkan pada uraian di atas, maka dapat disimpulkan bahwa dalam upaya manajemen pengembangan sumber daya manusia kependidikan di perguruan tinggi perlu dilakukan terlebih dahulu pemetaan SDM kependidikannya agar pembinaan dan pengembangan yang akan diberikan sesuai dengan situasi dan kondisi perguruan tinggi dan benar-benar sesuai dengan kebutuhan yang diperlukan. 


\section{DAFTAR PUSTAKA}

Cooper, Bruce S. Dkk. 2004. Better Policies, Better Schools; Theories and Applications. Boston: Pearson Education, Inc.

Fatah, N. 2001. Landasan Manajemen Pendidikan. PT Remaja Rosdakarya Bandung.

Hough, 1984. Educational Policy; An International Survey. Sidney: Croom Helm. Ltd.

Kompas, 2002. Perbaikan Mutu Pendidikan Hanus Terkait Upaya Pemberdayaan Sekolah. Kompas, 18 Desember 2002, hal. 9.

Nur Ali, 2004. Orientasi Pengembangan Fakultas Keperididikan, Malang: Makalah Diskusi LPM UIN Malang, tanggal 2 Juni 2004.

Rebore, R. 2004. Human Resources Administration in Education; A management Approach. Boston: Pearson Education, Inc.

Tilar, HAR., 1999. Beberapa Agenda Reformasi Pendidikan Nasional, Jakarta: Indonesia Tera. 